\title{
Induction of larval attachment and metamorphosis in the serpulid polychaete Hydroides elegans by dissolved free amino acids: mode of action in laboratory bioassays
}

\author{
Manfred Beckmann*, Tilman Harder, Pei-Yuan Qian** \\ Department of Biology, Hong Kong University of Science and Technology, Clearwater Bay, Kowloon, Hong Kong
}

\begin{abstract}
Larval settlement in the serpulid polychaete Hydroides elegans (Haswell) reportedly occurs in response to both an attractive bacterial film and polar, aliphatic dissolved free amino acids (DFAA). In this study, we tested whether the larval metamorphic response was caused by direct DFAA perception or by induction of DFAA-utilizing bacteria in assay dishes. Still-water laboratory assays were performed with sterile measures in the presence and absence of an antibiotic mixture $(2.5 \times$ $10^{-4} \mathrm{M}$ streptomycin, $1.0 \times 10^{-4} \mathrm{M}$ penicillin). In the absence of these antibiotics our results revealed a significant correlation between DFAA decrease rates, bacterial film development and larval metamor. phosis within a $24 \mathrm{~h}$ assay period. After $12 \mathrm{~h}$, DFAA concentrations decreased below the detection limit of $0.013 \mu \mathrm{M}$, the attached bacterial density in assay dishes was approx. $2 \times 10^{4}$ cells $\mathrm{mm}^{-2}$, and larval metamorphosis was insignificantly low (20\%). After $24 \mathrm{~h}$. DFAA were no longer detectable, the attached bacterial density was unchanged, and larval metamorphosis was significantly high (50\%). In contrast, naturally biofilmed dishes showed a significant metamorphic response of $50 \%$ after $12 \mathrm{~h}$. In analogous experiments in the presence of antibiotics, the percentage of larval metamorphosis varied between 3 and $34 \%$ after $24 \mathrm{~h}$ while the number of attached bacteria was low 10.5 to $5 \times 10^{3}$ cells $\mathrm{mm}^{-2}$ ). We assume that the metamorphic response in these treatments was caused by inductive, antibiotic-resistant bacteria. Our results suggest that larval metamorphosis was exclusively triggered by an inductive bacterial film rather than by direct larval perception of DFAA. Despite most sterile measures at the set-up of bioassays, bacteria were inevitably inoculated into test dishes as they were found associated with the larva and suspended in the larval culture water. Therefore, our results point to a systematic error in this established assay procedure. If putative signaling compounds serve as a nutrition source for larval settlement inducing marine bacteria, we conclude that an explicit investigation of a chemical metamorphic cue's efficacy is unreliable. The ecological significance of the transformation of DFAA into an attractive bacterial film for larval attachment and metamorphosis in $H$. elegans is discussed.
\end{abstract}

KEY WORDS: Hydroides elegans - Polychaete · Amino acids · Antibiotics · Biofilm - Bacteria Metamorphosis $\cdot$ Settlement induction

\section{INTRODUCTION}

Over the last 3 decades, intensive research has been conducted on the identification and perception of chemical signals in the marine environment (for reviews see Morse 1990, Pawlik 1992, Rodriguez et al.

\footnotetext{
- Present address: Cardiff School of Biosciences, Cardiff University, PO Box 915, Cardiff CF10 3TL, Wales, UK

- Corresponding author. E-mail: boqianpy@ust.hk
}

1993). The analysis of marine larval recruitment is undoubtedly of enormous economical interest with regard to fouling species that rapidly cover man-made submerged surfaces. Hence, successful prevention of biofouling in the marine environment requires detailed knowledge of the natural processes involved in larval attachment and metamorphosis. Therefore, it seems essential to describe and elucidate naturally occurring metamorphic cues and to investigate their modes of action on larvae of particular fouling species. Since 
reliable bioassays are a prerequisite for elaborating bioassay-guided cue isolation strategies, it is important to analyze the relationship between larval attachment behavior and the efficacy of biological, chemical and physical cues.

A variety of known factors indicate habitat suitability and/or induce larval attachment and metamorphosis in marine invertebrates. These include (1) biological cues such as natural bio-organic film (Zobell \& Allen 1935, Scheltema 1974, Pawlik 1992), (2) chemical cues including organic neurotransmitter-like inducers and inorganic ions, which imply the action of neuronal larval receptors in the initial process of attachment (Baloun \& Morse 1984, Yool et al. 1986, Jensen \& Morse 1990), and (3) physical properties such as surface-free energy, topography and hydrodynamics (Crisp 1974, 1984, Ryland 1974, 1977, Butman 1987, Walters et al. 1997).

In addition to barnacles and oysters, the clumped aggregations of the marine tubeworm Hydroides elegans constitute a severe fouling problem in Hong Kong waters. Since clumped distributions of conspecific individuals may result from gregarious larval settlement (Pawlik 1992), earlier investigations in our laboratory focused on chemical cues for larval settlement which were hypothesized to be released by conspecific and sympatric organisms in the same habitat. The ecological relevance of these studies was apparent since attachment and metamorphosis of $H$. elegans larvae in still-water laboratory assays were induced by the aqueous extract of conspecific adults (Bryan et al. 1997 ) and by the natural leachate of the bryozoan Bugula neritina (Bryan et al. 1998).

Recently, we reported the bioassay-guided chromatographic isolation of the presumptive larval settlement cue for Hydroides elegans from the extract of conspecific adults and the leachate of Bugula neritina (Harder \& Qian 1999). In both samples, we identified a biologically active mixture of 10 polar, aliphatic, dissolved free amino acids (DFAA), i.e. aspartic acid, glutamic acid, serine, histidine, glycine, arginine, alanine, asparagine, glutamine and taurine, in concentrations ranging from 0.2 (histidine) to $5.6 \mu \mathrm{M}$ (taurine).

Several studies have shown that a natural bioorganic film is highly efficient in inducing larval metamorphosis in Hydroides elegans as well (Hadfield 1986, Hadfield et al. 1994). Since amino acids and small peptides are reported to have high turnover rates due to rapid utilization by marine heterotrophic microorganisms (Amano et al. 1982, Ferguson \& Sunda 1984, Azam \& Cho 1987), we tested whether the identified amino acids were utilized by film-forming bacteria.

So far, only a few studies have examined the bacterial utilization and degradation of known larval settlement inducers, i.e. gamma-aminobutyric acid (GABA)
(Kaspar et al. 1991) and small peptides with arginine at the carboxy terminus (Browne et al. 1998). However, the potential transformation of a presumptive chemical cue for larval settlement into a biologically active bacterial film has never been investigated before.

With regard to the presumptive metamorphic induction of Hydroides elegans larvae by DFAA, we addressed the following questions in particular: How do DFAA influence larval metamorphic behavior? Do DFAA act directly on the larva as chemical signaling compounds or are they converted into a biologically active bacterial film, which subsequently induces larval metamorphic behavior in the laboratory bioassay? A series of experiments was designed in order to examine the percentage of larval metamorphosis together with bacterial abundance and DFAA concentrations in test dishes during the bioassay. They were performed in the presence and absence of antibiotics.

\section{MATERIALS AND METHODS}

Larval culture and bioassay procedures. Larvae were cultured according to the methods described in Harder \& Qian (1999). Competent larvae were sieved from culture batches ( $110 \mu \mathrm{m}$ mesh) and quickly resuspended into 2 sterilized glass beakers filled with $0.22 \mu \mathrm{m}$ filtered seawater (FSW) and FSW containing antibiotics $\left(2.5 \times 10^{-4} \mathrm{M}\right.$ streptomycin and $1.0 \times 10^{-4} \mathrm{M}$ penicillin), respectively.

Bioassays were performed following the methodology described in Bryan et al. (1998) and Harder \& Qian (1999). In addition, samples were generally filter-sterilized $(0.22 \mu \mathrm{m})$ prior to bioassays. Unless otherwise stated, bioassays with a sample under investigation were always conducted in a set of 2 treatments, in the presence and absence of the antibiotics given above. Twenty competent larvae were collected (GILSON, $\mathrm{P} 100)$ in the smallest volume of seawater possible $(\leq 100 \mu \mathrm{l})$ under a dissecting microscope from batches of high larval density and subsequently transferred into sterile polystyrene petri dishes (FALCON no. 1006) containing the dissolved sample under investigation in $4.5 \mathrm{ml} \mathrm{FSW}$. Each sample was investigated along with 5 replicates. Five additional replicates containing FSW only served as the controls in each experimental set (FSWC). Swimming, unattached or crawling larvae were not considered to have undergone metamorphosis. Larvae that had attached, but did not produce a tube and/or tentacles were considered to have undergone abnormal metamorphosis. Larvae that had attached, produced a tube, and grown tentacles were considered to have undergone normal metamorphosis. Hereafter, the term 'bioactive' characterizes a sample which induced a significantly higher percent- 
age of larval metamorphosis in laboratory bioassays than the FSWC.

Origin and preparation of samples used in experiments. The $500 \mathrm{D}$ ultrafiltrate of an aqueous extract of Hydroides elegans adult homogenate in the concentration of $0.1 \mathrm{mg}$ dry weight $\mathrm{ml}^{-1} \mathrm{FSW}(0.5 \mathrm{kDF})$ was used as a bioactive crude sample for the induction of larval attachment and metamorphosis. An artificial amino acid sample (AAS, Table 1) was prepared according to the previous analysis of the $0.5 \mathrm{kDF}$ in Harder \& Qian (1999).

Bacterial counts. Polystyrene petri dishes under investigation were emptied and immersed in a $0.22 \mu \mathrm{m}$ filtered solution of $3 \%$ formaldehyde in FSW for $10 \mathrm{~min}$. The dishes were rinsed with distilled water and air-dried. Attached bacteria were stained with Gram crystal violet (DIFCO) for $5 \mathrm{~min}$. Dishes were rinsed in distilled water, air-dried and the mean density of bacteria was determined under a light microscope at $1000 \times$ magnification based on counts of 12 fields of view.

Free amino acid analysis. Qualitative and quantitative DFAA analysis by pre-column derivatization with ortho-phthaldialdehyde (Lindroth \& Mopper 1979) was performed according to the methods described in Harder \& Qian (1999). All solvents and chemicals used in this study were r.g-grade; purified water was obtained from a Milli-Q Reagent-Water-System (Millipore).

Table 1. Hydroides elegans. Qualitative and quantitative amino acid analysis of biologically active samples. $0.5 \mathrm{kDF}$ $0.5 \mathrm{kD}$ filtrate of the aqueous extract of adult worm $H$ elegans body homogenate (mean concentration \pm SD of 2 measurements); AAS: artificially prepared amino acid sample

\begin{tabular}{|lccc|}
\hline Amino acid & $0.5 \mathrm{kDF}\left(\times 10^{-6} \mathrm{M}\right)$ & $( \pm \mathrm{SD})$ & AAS $\left(\times 10^{-6} \mathrm{M}\right)$ \\
\hline Asp & 1.290 & $(0.085)$ & 1.12 \\
Glu & 0.762 & $(0.083)$ & 0.76 \\
Ser & 1.244 & $(0.151)$ & 1.30 \\
His & 0.388 & $(0.238)$ & 0.20 \\
Gly & 4.301 & $(1.427)$ & 4.94 \\
Arg & 1.007 & $(0.189)$ & 1.02 \\
Ala & 1.951 & $(0.452)$ & 2.05 \\
Tyr & 0.823 & $(0.194)$ & - \\
Met & 0.341 & $(0.057)$ & - \\
Val & 0.814 & $(0.080)$ & - \\
Phe & 0.810 & $(0.156)$ & - \\
Ile & 0.641 & $(0.112)$ & - \\
Leu & 1.248 & $(0.215)$ & - \\
Lys & 0.930 & $(0.255)$ & - \\
Asn & 0.616 & $(0.121)$ & 0.43 \\
Gln & 0.878 & $(0.131)$ & 0.86 \\
Tau & 5.670 & $(0.439)$ & 5.62 \\
Trp & 0.170 & $(0.022)$ & - \\
\hline
\end{tabular}

Expt 1. This experiment was performed in order to investigate whether the metamorphic response of Hydroides elegans larvae to a natural bio-organic film was induced by waterborne compounds or by the surface-bound film. A natural bio-organic film was gained by submerging 10 polystyrene dishes at a pier in Port Shelter, Hong Kong, for $2 \mathrm{~d}$. After thoroughly rinsing biofilmed dishes with FSW, these dishes were divided into 2 groups ( 5 dishes group ${ }^{-1}$ ) and filled with $4.5 \mathrm{ml}$ FSW. The dishes of Group 1 were set up with 20 larvae dish $^{-1}$ whereas the dishes of Group 2 remained untreated. Both series were incubated at $25^{\circ} \mathrm{C}$ for $24 \mathrm{~h}$. After incubation, when 50 to $60 \%$ larval metamorphosis was observed in the dishes of Group 1, the conditioned seawater (biofilm conditioned seawater, BFCSW) in the dishes of Group 2 was sampled and aseptically transferred into sterile polystyrene dishes for a subsequent bioassay. The biofilmed dishes of Group 2 were thoroughly rinsed with FSW and refilled with $4.5 \mathrm{ml}$ FSW (biofilmed dishes, BFD). Finally, the $\mathrm{BFD}$ and BFCSW were assayed for $72 \mathrm{~h}$ along with the $0.5 \mathrm{kDF}$ and FSWC. This experiment was performed without antibiotics. The percentage of larval metamorphosis was statistically evaluated at $12,24,48$ and $72 \mathrm{~h}$.

Expt 2. This experiment was performed in order to examine the development of a bacterial film and its potential bioactivity in petri dishes containing the $0.5 \mathrm{kDF}$ during the bioassay. The experiment consisted of 2 sets, each including 4 samples, i.e. $0.5 \mathrm{kDF}$ and FSWC both in the presence and absence of antibiotics. A flowchart of the experimental design is given in Fig. 1.

Set 1: Of each sample $4.5 \mathrm{ml}$ was mixed with $100 \mu \mathrm{l}$ of larval batch water (sampled without any larvae from batches of high larval density). The samples were placed into petri dishes ( 7 replicates) and incubated for $72 \mathrm{~h}$ at $25^{\circ} \mathrm{C}$. The bacterial density was determined in 2 of these replicates at 24 and 72 h. After incubation, the remaining 5 dishes of each sample were emptied, thoroughly rinsed, refilled with $4.5 \mathrm{ml}$ FSW, and subsequently 20 larvae were placed into each of these dishes. The percentage of larval metamorphosis was evaluated at 24 and $72 \mathrm{~h}$.

Set 2: Seven replicate dishes were filled with the $0.5 \mathrm{kDF}$. Five replicates were set up with 20 larvae each and bioassayed along with the dishes of Set 1 and evaluated for larval metamorphosis at 24 and $72 \mathrm{~h}$. Two of the replicates were evaluated for bacterial abundance at 24 and $72 \mathrm{~h}$. Statistical analysis of percentage of larval metamorphosis was performed with the individual data records of Set 1 and Set 2 at $24 \mathrm{~h}$. The FSWC in Set 2 represented the control in Expt 2.

Expt 3. In order to investigate whether the development of a bacterial film was correlated with a decrease of amino acids over time, DFAA concentrations were 
Set 1

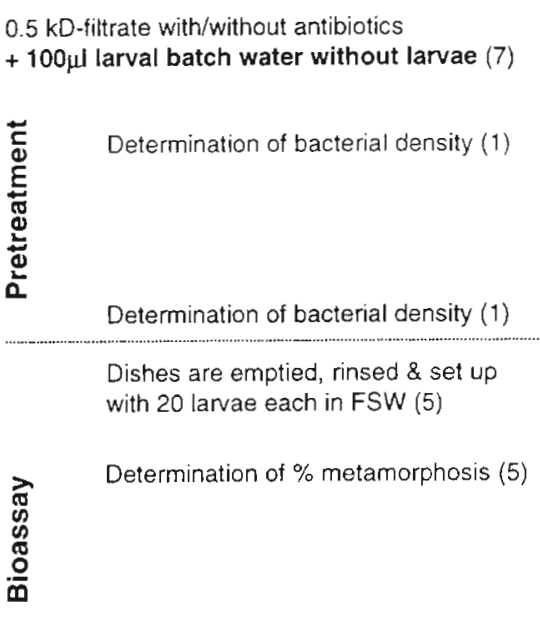

Determination of \% metamorphosis (5)

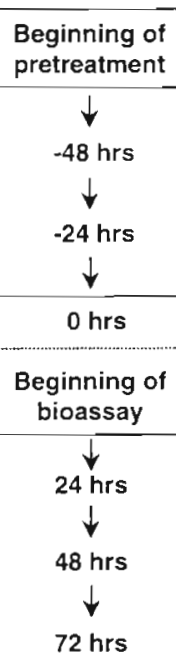

Set 2

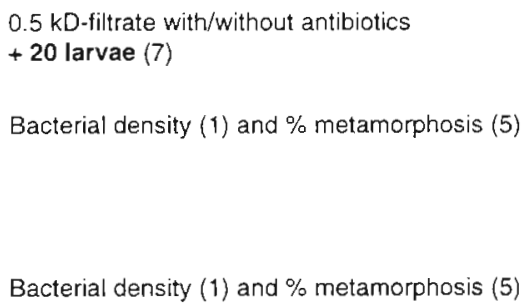

$0.5 \mathrm{kD}$-filtrate with/without antibiotics

+20 larvae $(7)$

Bacterial density (1) and \% metamorphosis (5)

Bacterial density (1) and \% metamorphosis (5)

Fig. 1. Design of Expt 2. Numbers in brackets indicate the number of replicate dishes

determined together with percentage of larval metamorphosis and bacterial abundance in test dishes. Ten sterile petri dishes were filled with $4.5 \mathrm{ml}$ of $0.5 \mathrm{kDF}$ each; another 10 dishes were filled with $4.5 \mathrm{ml}$ of the AAS. Twenty competent larvae were added into each dish. Five replicates of each sample were used to monitor the larval metamorphic response whilst the bacterial density was determined in 4 dishes at $12,24,48$ and $72 \mathrm{~h}$. In the remaining dish of each sample, DFAA concentrations were measured every $4 \mathrm{~h}$. Additionally, DFAA concentrations were monitored in the following experimental conditions: dishes containing the $0.5 \mathrm{kDF}$ only, $0.5 \mathrm{kDF}$ in antibiotics, and $0.5 \mathrm{kDF}$ plus $100 \mathrm{\mu l}$ larval batch water. In order to do so, a $50 \mu$ aliquot of a sample under investigation was sampled aseptically, immediately frozen in liquid nitrogen and stored at $-20^{\circ} \mathrm{C}$ until amino acid analysis. Statistical analysis of percentage of larval metamorphosis was performed with data gained at 12 and $24 \mathrm{~h}$.

Statistical analysis. The data of percentage of larval metamorphosis in response to experimental treatments were arcsine-transformed before statistical analysis. Those replicates in which no larvae metamorphosed were given the value of $1 / 4 n$ ( $n=$ number of larvae in a single treatment) to improve the arcsine transformation (Zar 1996). The normality assumption was verified with Shapiro-Wilk's W-test (Shapiro \& Wilk 1965). To analyze the data, 1-way ANOVA followed by Tukey's multiple comparison test $(\alpha=0.05)$ was performed. Data that did not meet the normality assumption of parametric analysis were analyzed using nonparametric statistics. This was done by transforming values to ranks and then applying 1-way ANOVA followed by Tukey's multiple comparison test $(\alpha=0.05)$ to the data (Conover \& Iman 1981). In Expts 2 and 3, data were analyzed with a 2-factor ANOVA with equal replicates (2-way ANOVA) to compare the larval metamorphic response to bioactive samples in the presence or absence of antibiotics. The figure legends state the applied statistical analyses. The data presented in all figures are not transformed.

\section{RESULTS}

\section{Expt 1: Larval metamorphosis in response to BFD, BFCSW and 0.5kDF}

At $12 \mathrm{~h}$, significantly more larvae had metamorphosed in BFD compared to those containing the $0.5 \mathrm{kDF}$ ( $\mathrm{p}<$ 0.0005 , Tukey's test). However, no further significant difference was observed between replicates of the $0.5 \mathrm{kDF}$ and the BFD in the ongoing bioassay ( $p=0.958$, Tukey's test). In comparison to 50-60\% larval metamorphosis after $24 \mathrm{~h}$ in dishes of Group 1, the BFD of Group 2 revealed a very similar larval metamorphic response at this time. From 24 to $72 \mathrm{~h}$, the percentage of metamorphosis in BFD was significantly higher compared to the FSWC and BFCSW (Fig. 2, p $<0.005$, Tukey's test). Throughout the entire bioassay, no significant difference in percentage of larval metamorphosis was observed between BFCSW and the FSWC ( $p>0.06$, Tukey's test).

\section{Expt 2: Investigation of bacterial film development throughout the bioassay}

Incubation of sterile petri dishes containing the $0.5 \mathrm{kDF}$ plus $100 \mu \mathrm{l}$ of larval batch water for $72 \mathrm{~h}$ (Set 1) resulted in a bacterial film of high density $70520 \pm$ 


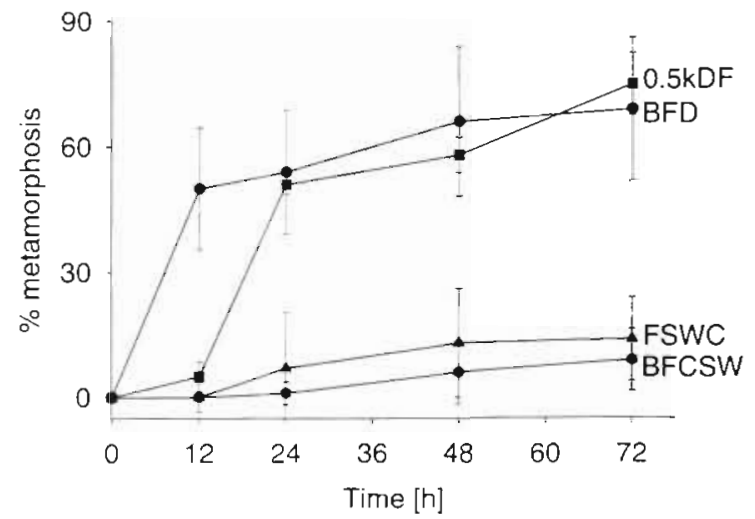

Fig. 2. Hydroides elegans. Expt 1. Percentage of larval metamorphosis of $H$. elegans in response to the $0.5 \mathrm{kD}$ filtrate of an aqueous extract of conspecific adult homogenate $(0.5 \mathrm{kDF})$, biofilmed dishes (BFD), biofilm conditioned seawater (BFCSW) and a filtered seawater control (FSWC) after 12, 24, 48 and $72 \mathrm{~h}$ of the bioassay. Data plotted are mean \pm SD of replicates. One-way ANOVA, $p<0.0001$

13333 cells $\mathrm{mm}^{-2}$, Table 2). In the subsequent bioassay, the percentage of larval metamorphosis at $24 \mathrm{~h}$ was determined as $53 \pm 10 \%$. The bacterial density in dishes containing the other samples of Set 1 did not exceed $5503 \pm 872$ cells $\mathrm{mm}^{-2}$ (Table 2). A significant influence of antibiotics on attached bacterial density and larval metamorphosis in the dishes of Set 1 was observed at $24 \mathrm{~h}$ (Fig. 3A, 2-way ANOVA, p < 0.05).

At 24 and $72 \mathrm{~h}$, the bacterial density in dishes containing the $0.5 \mathrm{kDF}$ (Set 2) was determined as $22378 \pm$ 8126 and $51805 \pm 6049$ cells $\mathrm{mm}^{-2}$, respectively. In the other dishes of Set 2 it did not exceed $1285 \pm 964$ and $5469 \pm 1099$ cells $\mathrm{mm}^{-2}$, respectively (Table 2 ). A significant influence of antibiotics on mean density of attached bacterial cells and larval metamorphosis in the dishes of Set 2 was observed at 24 h (Fig. 3B, 2-way ANOVA, $p<0.005$ ). The data gained for the $0.5 \mathrm{kDF}$ in Set 2 demonstrated the development of a bacterial film within the first $24 \mathrm{~h}$ of the bioassay and revealed $43 \pm$ $17 \%$ larval metamorphosis at this time (Fig. 3B, Table 2). In the course of the bioassay, the larval metamorphic response remained steady in dishes which had been pretreated with the $0.5 \mathrm{kDF}(53 \pm 10$ to $54 \pm 11 \%$, Set 1) whereas an increase in both percentage of larval metamorphosis $(43 \pm 17$ to $73 \pm 16 \%)$ and bacterial density (22 $378 \pm 8126$ to $51805 \pm 6049$ cells $\mathrm{mm}^{-2}$, Table 2$)$ was recorded in dishes containing the $0.5 \mathrm{kDF}$ (Set 2)

Table 2. Hydroides elegans. Expt 2. Mean density and SD of bacterial cells and percentage of larval metamorphosis in test dishes containing $0.5 \mathrm{kDF}$ and FSWC. Negative values in the time scale indicate the pretreatment of dishes (Set 1); positive values represent the evaluation of the bioassay (Set 2). Mean density of bacterial cells was based on counts of 12 fields at $1000 \times$ magnification under light microscope in 1 dish per treatment. $(+A B)$ : treatments in the presence of antibiotics

\begin{tabular}{|c|c|c|c|c|c|c|c|c|c|}
\hline \multirow{3}{*}{$\begin{array}{l}\text { Sample } \\
0.5 \mathrm{kDF}\end{array}$} & \multirow{3}{*}{$\begin{array}{c}\text { Time (h) } \\
-72\end{array}$} & \multicolumn{4}{|c|}{ Set 1} & \multicolumn{4}{|c|}{ Set 2} \\
\hline & & \multicolumn{2}{|c|}{$\begin{array}{l}\text { Mean density of } \\
\text { bacterial cells } \\
\qquad( \pm \mathrm{SD})\end{array}$} & \multicolumn{2}{|c|}{$\begin{array}{l}\text { Mean \% larvae } \\
\text { metamorphosed } \\
\qquad( \pm S D)\end{array}$} & \multicolumn{2}{|c|}{$\begin{array}{c}\text { Mean density of } \\
\text { bacterial cells mm } \mathrm{mm}^{-2} \\
\mathrm{~mm}^{-2}( \pm \mathrm{SD})\end{array}$} & \multicolumn{2}{|c|}{$\begin{array}{l}\text { Mean \% larvae } \\
\text { metamorphosed } \\
\qquad( \pm \mathrm{SD})\end{array}$} \\
\hline & & 0 & $(0)$ & - & - & - & - & - & - \\
\hline & -48 & 9114 & $(2277)$ & - & - & - & - & - & - \\
\hline & 0 & 70520 & (13333) & 0 & $(0)$ & 0 & $(0)$ & 0 & $(0)$ \\
\hline & 24 & - & - & 53 & $(9.8)$ & 22378 & (8126) & 43 & $(16.8)$ \\
\hline & 72 & - & - & 54 & $(10.9)$ & 51805 & (6049) & 73 & $(16.4)$ \\
\hline \multirow[t]{5}{*}{ FSWC } & -72 & 0 & $(0)$ & - & - & - & - & - & - \\
\hline & -48 & 642 & $(430)$ & - & - & - & - & - & - \\
\hline & 0 & 2812 & $(867)$ & 0 & $(0)$ & 0 & $(0)$ & 0 & $(0)$ \\
\hline & 24 & - & - & 14 & (7.4) & 1111 & $(781)$ & 1 & (2.2) \\
\hline & 72 & - & - & 18 & (8.4) & 5469 & (1099) & 2 & $(2.8)$ \\
\hline $0.5 \mathrm{kDF}$ & -72 & 0 & $(0)$ & - & - & - & - & - & - \\
\hline \multirow[t]{4}{*}{$+\mathrm{AB}$} & -48 & 1910 & (1561) & - & - & - & - & - & - \\
\hline & 0 & 3368 & $(1062)$ & 0 & $(0)$ & 0 & $(0)$ & 0 & $(0)$ \\
\hline & 24 & - & - & 3 & (2.7) & 1285 & $(964)$ & 3 & (4.5) \\
\hline & 72 & - & - & 8 & $(6.7)$ & 3663 & (1607) & 49 & (5.5) \\
\hline FSW & -72 & 0 & $(0)$ & - & - & - & - & - & - \\
\hline \multirow[t]{4}{*}{$+A B$} & -48 & 486 & $(224)$ & - & - & - & - & - & - \\
\hline & 0 & 5503 & $(872)$ & 0 & $(0)$ & 0 & $(0)$ & 0 & $(0)$ \\
\hline & 24 & - & - & 3 & (4.5) & 729 & $(668)$ & 1 & (2.2) \\
\hline & 72 & - & - & 5 & (6.1) & 4549 & $(1240)$ & 3 & (4.5) \\
\hline
\end{tabular}




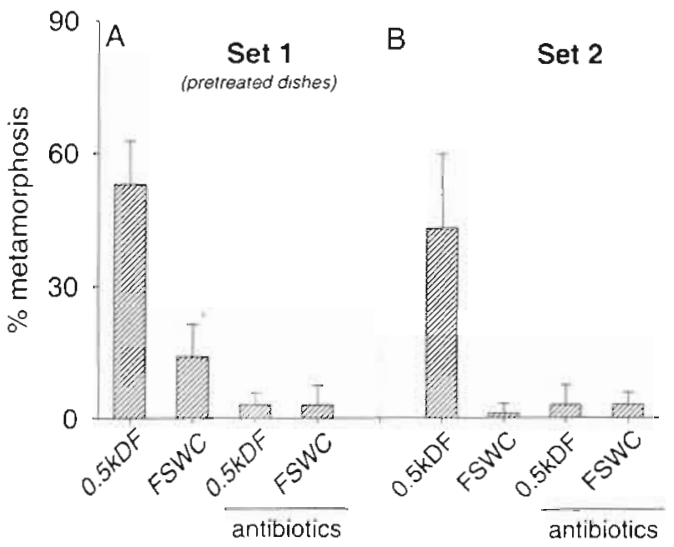

Fig. 3. Hydroides elegans. Expt 2. (A) Percentage of larval metamorphosis after $24 \mathrm{~h}$ in response to test dishes pretreated with $0.5 \mathrm{kDF}$ and FSWC (Set 1). Two-way ANOVA, $\mathrm{p}<0.05$. (B) Percentage of larval metamorphosis after $24 \mathrm{~h}$ in response to test dishes containing $0.5 \mathrm{kDF}$ and FSWC (Set 2). The FSWC in Set 2 represented the control in this experiment. Two-way ANOVA, $p<0.005$. Data plotted are mean $+\mathrm{SD}$ of 5 replicates

\section{Expt 3: Determination of DFAA concentrations, percentage of larval metamorphosis and bacterial abundance}

\section{Bacterial densities}

In the absence of antibiotics, the bacterial density in dishes containing the $0.5 \mathrm{kDF}$, the AAS, and the FSWC reached $12916 \pm 3428$ to $20364 \pm 5613$ cells $\mathrm{mm}^{-2}$ at $12 \mathrm{~h}$ (Fig. 4B). These data did not notably change throughout the observation period of $72 \mathrm{~h}$ (Table 3 ). However, in the presence of antibiotics the bacterial density did not exceed $1059 \pm 1397$ cells $\mathrm{mm}^{-2}$ at $12 \mathrm{~h}$ (Fig. 4B) and reached a maximum of $6996 \pm 2868$ cells $\mathrm{mm}^{-2}$ after $72 \mathrm{~h}$ (Table 3 ).

\section{Percentage of larval metamorphosis}

The 2-factor ANOVA demonstrated a significant effect of antibiotics on percentage of larval metamorphosis in dishes containing the $0.5 \mathrm{kDF}$, the AAS, and the FSWC at 12 h (2-way ANOVA, $p<0.005$, Fig. 4A). This effect was much more pronounced at $24 \mathrm{~h}$ (2-way ANOVA, $\mathrm{p}<0.0001$, Fig. 4C). At this time, the percentage of larval metamorphosis in all treatments was approximately twice as high compared to the data at $12 \mathrm{~h}$ (Fig. 4C). In the absence of antibiotics, significantly more larvae metamorphosed in dishes containing the $0.5 \mathrm{kDF}$ and the AAS compared with the FSWC (Fig. 4C, $p<0.005$, Tukey's test). No significant difference in percentage of larval metamorphosis was ob- served between the $0.5 \mathrm{kDF}$ and the AAS $(\mathrm{p}=0.99$, Tukey's test). However, in the presence of antibiotics these 2 samples differed significantly $(p<0.005$, Tukey's test).

Comparing the metamorphic response in each sample of both treatments up to $72 \mathrm{~h}$, a doubling in percentage of larval metamorphosis was observed between 12 and 24 h (Fig. 5). However, a different rate of increase was observed in the subsequent observation period from 24 to $72 \mathrm{~h}$. In contrast to the observation between 12 and $24 \mathrm{~h}$, the increase in percentage of larval meta-

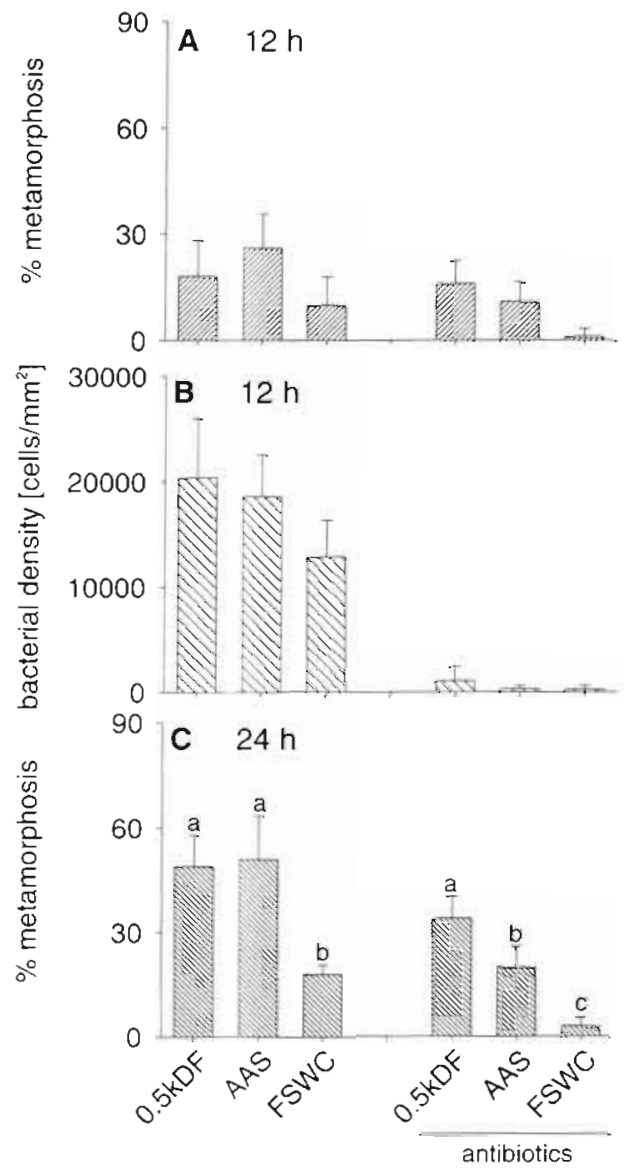

Fig. 4. Hydroides elegans. Expt 3. (A) Percentage of larval metamorphosis after $12 \mathrm{~h}$ in response to $0.5 \mathrm{kDF}$, an artificially prepared amino acid sample (AAS), and FSWC. One-way ANOVA followed by Tukey's multiple comparisons test $\alpha=$ 0.05 ) was individually performed for the treatments in the presence $(p=0.95)$ and absence $(p=0.06)$ of antibiotics. Data plotted are mean + SD of 5 replicates. (B) Bacterial density after $12 \mathrm{~h}$ in test dishes containing the samples given above. Data plotted are mean + SD based on counts of 12 fields at $1000 \times$ magnification. (C) Percentage of larval metamorphosis after $24 \mathrm{~h}$ in response to the samples given above. One-way ANOVA followed by Tukey's multiple comparisons test was individually performed for the treatments in the presence $(p<0.0001)$ and absence $(p<0.0005)$ of antibiotics. Data plotted are mean + SD of 5 replicates. Data that are significantly different are indicated by different letters above the bars 
Table 3. Hydroides elegans. Expt 3. Mean density of bacterial cells and percentage of larval metamorphosis in test dishes containing $0.5 \mathrm{kDF}$, AAS, and FSWC after $12,24,48$ and $72 \mathrm{~h}$ of the bioassay procedure. Bacterial counts were based on counts of 12 fields at $1000 \times$ magnification under a light microscope in 1 dish per treatment

\begin{tabular}{|c|c|c|c|c|c|c|c|c|c|}
\hline \multirow{3}{*}{$\begin{array}{l}\text { Sample } \\
0.5 \mathrm{kDF}\end{array}$} & \multirow{3}{*}{$\begin{array}{c}\text { Time (h) } \\
\text { 12 }\end{array}$} & \multicolumn{4}{|c|}{ Without antibiotics } & \multicolumn{4}{|c|}{ With antibiotics } \\
\hline & & \multicolumn{2}{|c|}{$\begin{array}{c}\text { Mean density of } \\
\text { bacterial cells } \mathrm{mm}^{-2} \\
( \pm \mathrm{SD})\end{array}$} & \multicolumn{2}{|c|}{$\begin{array}{c}\text { Mean \% larvae } \\
\text { metamorphosed } \\
\qquad( \pm \mathrm{SD})\end{array}$} & \multicolumn{2}{|c|}{$\begin{array}{c}\text { Mean density of } \\
\text { bacterial cells } \mathrm{mm}^{-2} \\
( \pm \mathrm{SD})\end{array}$} & \multicolumn{2}{|c|}{$\begin{array}{c}\text { Mean } \% \text { larvae } \\
\text { metamorphosed } \\
\qquad( \pm S D)\end{array}$} \\
\hline & & 20364 & (5613) & 18 & $(10.4)$ & 1059 & $(1397)$ & 16 & $(6.5)$ \\
\hline & 24 & 23732 & $(4910)$ & 49 & [8.9] & 5035 & $(2606)$ & 34 & (6.5) \\
\hline & 48 & 19271 & $(4603)$ & 58 & $(6.7)$ & 5781 & (2932) & 52 & $(5.7)$ \\
\hline & 72 & 18750 & (8008) & 61 & $(10.8)$ & 6996 & $(2868)$ & 64 & $(7.4)$ \\
\hline \multirow[t]{4}{*}{ AAS } & 12 & 18611 & (3932) & 26 & $(9.6)$ & 295 & (314) & 11 & (5.5) \\
\hline & 24 & 17500 & (2514) & 51 & $(12.5)$ & 469 & $(603)$ & 20 & $(6.1)$ \\
\hline & 48 & 21180 & $(2218)$ & 65 & $(9.4)$ & 5243 & $\{918\}$ & 30 & (7.1) \\
\hline & 72 & 14670 & $(6813)$ & 68 & $(12.6)$ & 5104 & (1642) & 43 & $(9.8)$ \\
\hline \multirow[t]{4}{*}{ FSWC } & 12 & 12916 & $(3428)$ & 10 & $(7.9)$ & 260 & $(357)$ & 1 & $(2.2)$ \\
\hline & 24 & 19583 & $(1584)$ & 18 & $(2.7)$ & 2413 & $(1712)$ & 3 & $(2.7)$ \\
\hline & 48 & 16493 & $(5868)$ & 24 & $(5.5)$ & 3056 & (1386) & 11 & $(4.2)$ \\
\hline & 72 & 10312 & $(3770)$ & 28 & $(4.5)$ & 5972 & (1405) & 18 & $\{5.7\}$ \\
\hline
\end{tabular}

morphosis was approximately 200 and $50 \%$ of the increment in treatments in the presence and absence of antibiotics, respectively (Fig. 5, Table 3).

\section{DFAA analysis}

Very similar time-dependent DFAA concentration plots were obtained for the 2 samples under investigation. The results given here for the $0.5 \mathrm{kDF}$ therefore exemplify the results for the AAS as well. Within $72 \mathrm{~h}$, DFAA concentrations in the $0.5 \mathrm{kDF}$ were dependent on the specific experimental conditions. In dishes

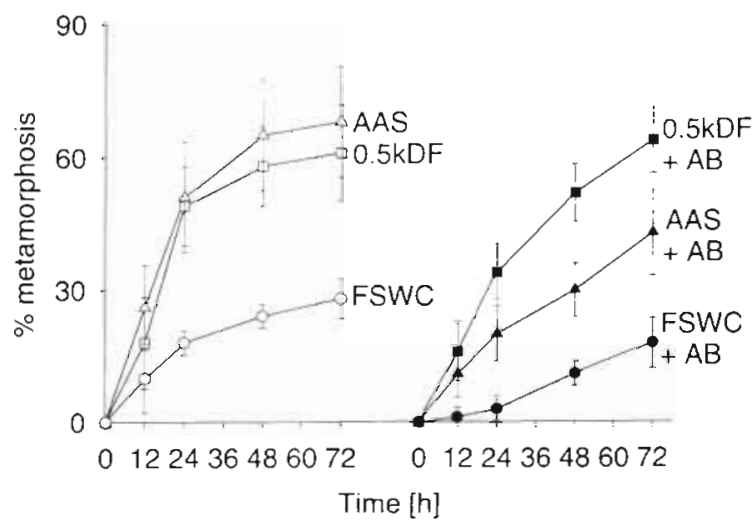

Fig. 5. Hydroides elegans. Expt 3. Percentage of larval metamorphosis in response $0.5 \mathrm{kDF}, \mathrm{AAS}$, and FSWC after 12,24 48 and $72 \mathrm{~h}$ of the bioassay. Results are presented for treatments in the presence (1-way ANOVA, $p<0.0001)$ and absence $(1$-way ANOVA, $p<0.0001)$ of antibiotics. Data plotted are mean $\pm \mathrm{SD}$ of 5 replicates containing the $0.5 \mathrm{kDF}$ only, DFAA concentrations remained nearly constant both in the presence and absence of antibiotics. When larvae or larval batch water were provided together with the $0.5 \mathrm{kDF}$ in the absence of antibiotics, DFAA concentrations significantly decreased over time. Specifically, in the dish containing the $0.5 \mathrm{kDF}$ with 20 larvae, all the DFAA with the exception of taurine reached the detection limit of $0.013 \mu \mathrm{M}$ at $12 \mathrm{~h}$ (Fig. 6). DFAA concentrations in the dish containing the $0.5 \mathrm{kDF}$ with $100 \mu$ larval batch water revealed a comparable tendency (Fig. 7). At $12 \mathrm{~h}$, the concentrations of 6 out of the 17 DFAA were below the detection limit; an additional 5 DFAA were no longer detectable at $16 \mathrm{~h}$. At $48 \mathrm{~h}$, the concentrations of all DFAA were below the detection limit.

In the presence of antibiotics, the fate of DFAA in dishes containing the $0.5 \mathrm{kDF}$ with larvae was characterized by the following trend: DFAA concentrations remained nearly invariable for a period of $12 \mathrm{~h}$. After 20 and 36 h, 6 and 14 DFAA were below the detection limit, respectively (Fig. 8). The taurine concentration remained nearly constant within the observation period of $72 \mathrm{~h}$, and the amounts of histidine and aspartic acid showed a lower rate of depletion than the other DFAA. However, histidine was imprecisely quantified due to an unavoidable overlap with an unknown derivative of the antibiotics in the HPLC chromatogram.

\section{Summary of Expt 3 results}

A comparison of the larval metamorphic response, bacterial densities and DFAA concentrations over $72 \mathrm{~h}$ 


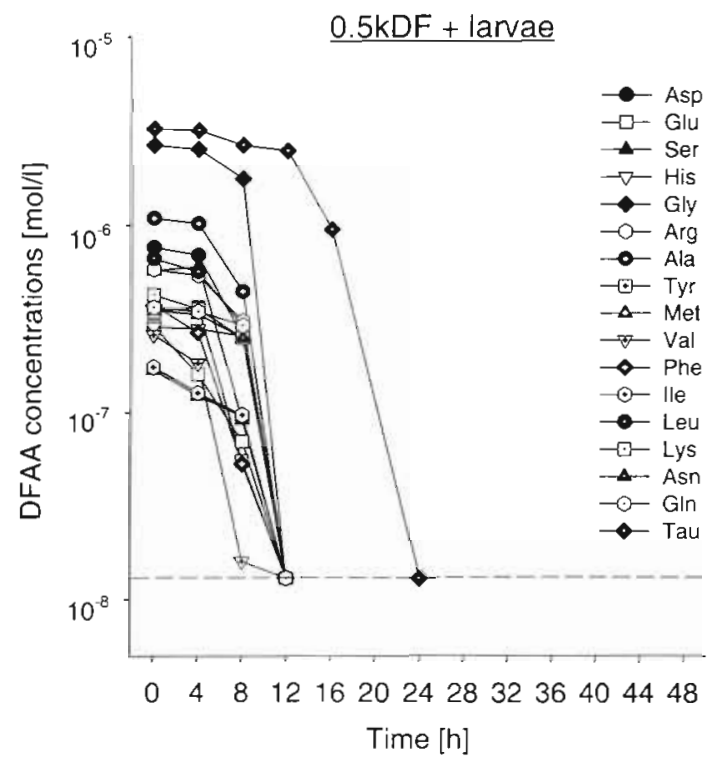

Fig. 6. Expt 3. Dissolved free amino acid (DFAA) concentrations as a function of time in test dishes containing $0.5 \mathrm{kDF}$ with 20 larvae. Dashed line: detection limit of $0.013 \mu \mathrm{M}$.

Amino acids are designated with 3-letter abbreviations

in dishes containing the $0.5 \mathrm{kDF}$ in the absence of antibiotics revealed the following correlation: At $12 \mathrm{~h}$, DFAA concentrations with the exception of taurine decreased to values below the detection limit (Fig, 6). At the same time, the bacterial density reached a max-

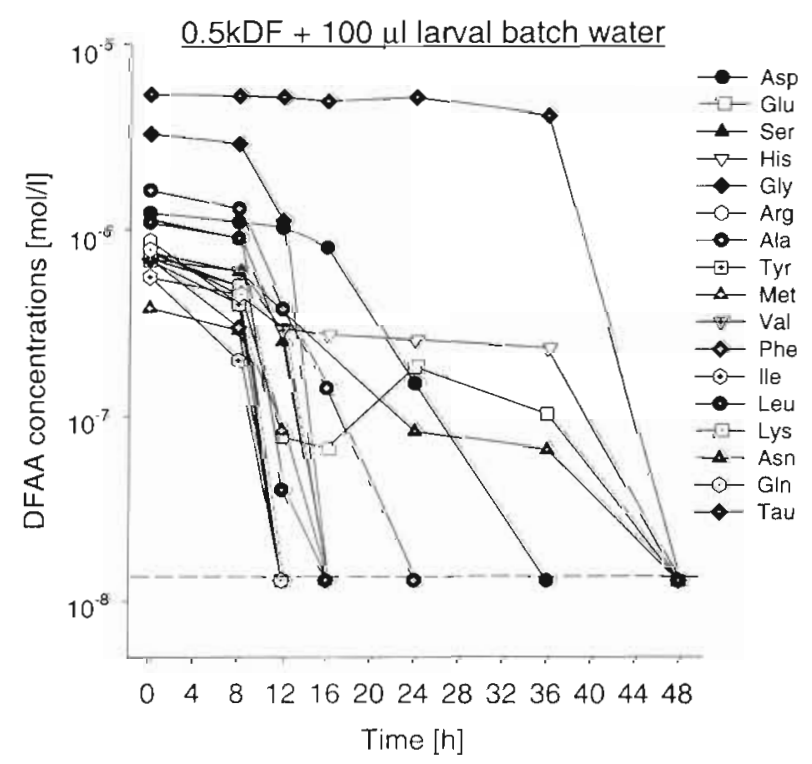

Fig. 7. Expt 3. DFAA concentrations as a function of time in test dishes containing $0.5 \mathrm{kDF}$ with $100 \mu \mathrm{l}$ of larval batch water. Dashed line: detection limit of $0.013 \mu \mathrm{M}$. Amino acids are designated with 3-letter abbreviations

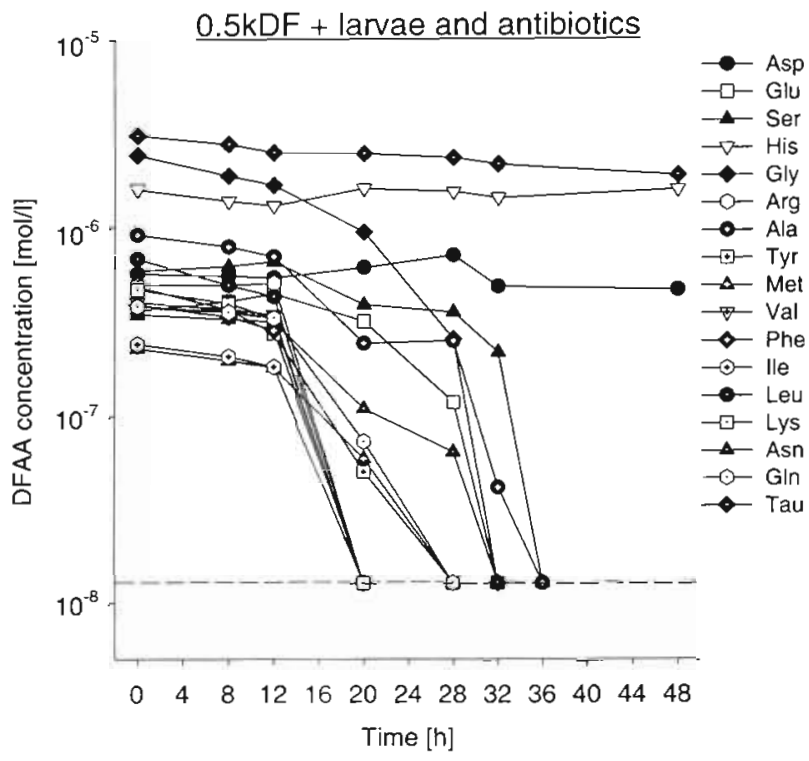

Fig. 8. Expt 3. DFAA concentrations as a function of time in test dishes containing the $0.5 \mathrm{kDF}$ with 20 larvae in the presence of antibiotics. Dashed line: detection limit of $0.013 \mu \mathrm{M}$.

Amino acids are designated with 3-letter abbreviations

imum and remained nearly constant in the course of the bioassay (Table 3). At $12 \mathrm{~h}$, the metamorphic response was not significantly different from the FSWC ( $p=0.95$, Tukey's test $)$ whereas a significant difference was observed at $24 \mathrm{~h}$ ( $p<0.005$. Tukey's test). Within the following $48 \mathrm{~h}$, the percentage of larval metamorphosis did not notably change (Fig. 5).

In dishes containing the $0.5 \mathrm{kDF}$ in the presence of antibiotics, the bacterial density was comparatively low (Table 3 ) and the decrease of DFAA concentrations was insignificant at $12 \mathrm{~h}$ (Fig. 8). Although the bacterial density appeared to be insignificant, the percentage of larval metamorphosis was almost as high as in the $0.5 \mathrm{kDF}$ in the absence of antibiotics by this time. Within the following $24 \mathrm{~h}$, the concentrations of 14 out of the 17 DFAA dropped below the detection limit (Fig. 8). Between 24 and $72 \mathrm{~h}$, the percentage of larval metamorphosis changed notably (Fig. 5).

\section{DISCUSSION}

The aqueous homogenate of Hydroides elegans adults and the leachate of the bryozoan Bugula neritina have been described to contain a chemical inducer for larval attachment and metamorphosis in $H$. elegans (Bryan et al. 1997, 1998). Recently, we demonstrated that a complex of polar, aliphatic amino acids in these samples caused larval metamorphosis in laboratory assays (Harder \& Qian 1999). 
In the present study, most sterile precautions were taken in the set-up of bioassays, i.e. presence of antibiotics, filter sterilization of samples under investigation, and application of samples into sterile petri dishes. Despite these precautionary measures, a bacterial film was already observed after $12 \mathrm{~h}$ of the bioassay on the surface of test dishes containing the $0.5 \mathrm{kDF}$ or the AAS (Table 3, Fig. 4B). Our results suggest that film-forming bacteria were inoculated into test dishes together with larvae and the larval batch water. In Expt 2, the addition of only $100 \mu \mathrm{l}$ larval batch water to the $0.5 \mathrm{kDF}$ resulted in a bacterial film of high density after $24 \mathrm{~h}$. The bacterial density in test dishes containing both larvae and larval batch water was significantly higher compared to that in dishes containing larval batch water only. Therefore, it seems that in addition to the number of suspended bacteria in the larval batch water, bacteria associated with the larva were transferred into the test dish.

In Expt 3, DFAA concentrations remained invariable in dishes containing the $0.5 \mathrm{kDF}$ only and in the presence of antibiotics. However, a significant decrease of DFAA concentrations was observed in dishes additionally containing larvae and/or larval batch water regardless of the presence of antibiotics (Figs. 6 to 8 ). Hence, the rate of DFAA decrease was not attributable to surface adsorption in the petri dish. We rather interpret the reduction of DFAA as a result of utilization by inoculated bacteria, which subsequently filmed the dish surface. Marine bacteria are effective processors of dissolved organic molecules, most likely through active transport across the periplasmic membrane (Crawford et al. 1974). Large peptides must be hydrolyzed by bacterial extracellular enzymes before uptake can be accomplished (Hoppe 1991) whereas DFAA can be directly taken up by the cells (Amano et al. 1982, Ferguson \& Sunda 1984, Azam \& Cho 1987. Simon 1991). In Expt 3, DFAA decrease rates were rapid (24 to $325 \mathrm{nM} \mathrm{h}^{-1}$ ) in dishes containing the $0.5 \mathrm{kDF}$ and larvae (Fig. 6). In fact, they were similar to bacterial uptake rates of 15 to $600 \mathrm{nM} \mathrm{h}^{-1}$ found by Coffin (1989).

Bacterial utilization of amino acids may likewise account for the clear correlation between the decrease of DFAA concentrations and the bacterial abundance in test dishes. At $12 \mathrm{~h}, \mathrm{DFAA}$ concentrations with the exception of taurine were below the detection limit (Fig. 6). At the same time, the bacterial density reached a maximum and gradually decreased in the course of the bioassay (Table 3). This observation resembles the normal bacterial growth cycle in a batch culture, characterized by an exponential increase in numbers followed by a maximum stationary phase and a subsequent decrease in numbers due to a limited energy source for the maintenance of viability (Gerhardt et al. 1994).
In the analogous bioassay in the presence of antibiotics, the number of bacteria in test dishes was significantly lower (Table 3). This observation was paralleled by slower rates of DFAA decrease (Fig. 8). DFAA concentrations remained almost unchanged whereas they were no longer detectable after $12 \mathrm{~h}$ in the analogous experiment without antibiotics (Fig. 6).

Furthermore, the larval metamorphic response was clearly correlated with the development of a bacterial film in test dishes. The results of Expt 3 revealed that after $12 \mathrm{~h}$, when DFAA concentrations were already close to the detection limit (Fig, 6) and the density of attached bacteria was almost maximal in the absence of antibiotics, the percentage of larval metamorphosis was low and not significantly different from that in the FSWC (Fig. 4A,B). This result suggests that larvae neither responded to the composite amino acid cue nor to the developing bacterial film within the first $12 \mathrm{~h}$ of the bioassay. However, after $24 \mathrm{~h}$, when DFAA concentrations were observed below the detection limit (Fig, 6) the percentage of larval metamorphosis was remarkably high. The pronounced response during the interval from 12 to $24 \mathrm{~h}$ was obviously exclusively triggered by an inductive bacterial film, which had developed within the first $12 \mathrm{~h}$ of the bioassay (Fig. 4B,C). Compared to the rapid increase of percentage of larval metamorphosis from 12 to $24 \mathrm{~h}$, the increment from 24 to $72 \mathrm{~h}$ was not as marked (Fig. 5, Table 3). Within the same period, the bacterial density remained nearly constant. Therefore, we suppose that the development of an inductive bacterial film within the first $12 \mathrm{~h}$ of the bioassay displays a decisive process for subsequent induction of larval metamorphosis in the interval from 12 to $24 \mathrm{~h}$.

The utilization of DFAA by bioactive film-forming bacteria was also supported by the results of Expts 1 and 2. Pre-incubation of the $0.5 \mathrm{kDF}$ with larval batch water for $72 \mathrm{~h}$ resulted in a bacterial film of high density (Table 2 ). In the subsequent bioassay with these biofilmed dishes, a high percentage of larval metamorphosis was observed (Fig. 3A, Table 2). Owing to the treatment of test dishes in Set 1, i.e. thorough cleaning with seawater following the incubation, the metamorphic induction of larvae after $24 \mathrm{~h}$ was therefore entirely caused by a bioactive bacterial film. Larvae in dishes of Set 1 immediately responded to the inductive bacterial film, which was characterized by almost invariant density over time while in dishes of Set 2 the increase in the percentage of larval metamorphosis paralleled the increase of bacterial density. In Expt 1, approximately $50 \%$ larval metamorphosis was observed in response to a $2 \mathrm{~d}$ old natural biofilm at $12 \mathrm{~h}$. The metamorphic response in assays with the $0.5 \mathrm{kDF}$ was still low at this time (Fig. 2). However, notably more larvae metamorphosed in the interval 
from 12 to $24 \mathrm{~h}$. This observation may be correspondingly explained by bacterial utilization of the $0.5 \mathrm{kDF}$ components. Importantly, the percentage of larval metamorphosis after $24 \mathrm{~h}$ was nearly the same in bioassays with both the $0.5 \mathrm{kDF}$ and the natural biofilm. Moreover, the results of Expt 1 revealed that the bioactivity of the natural biofilm was associated with the film itself rather than with dissolved compounds in biofilm conditioned seawater.

The results of analogous experiments performed in the presence of streptomycin and penicillin lead to the following conclusions. Firstly, the suspended bacterial abundance in assay dishes must have been relatively high considering the decrease of DFAA concentrations in Expt 3 which indirectly indicated an incremental bacterial density in assay dishes. Remarkably, the DFAA uptake rates of 11 to $268 \mathrm{nM} \mathrm{h}^{-1}$ were comparable to the results in the analogous experiment without antibiotics. This conclusion is supported by the fact that a significant proportion of marine bacteria is reportedly resistant to various antibiotics (Dias et al. 1991, Attrassi et al. 1993). Secondly, the observation of low numbers of attached, resistant bacteria suggests that the antibiotics might have impaired the bacterial competence for attachment. This effect was apparent in both sets of Expt 2, owing to both low bacterial density and low percentage of larval metamorphosis after $24 \mathrm{~h}$. However, variations in bacterial density and composition in the larval batch water may be responsible for the differences in mean densities of bacterial cells and, consequently, the differences in larval metamorphic rates in Expts 2 and 3.

Recent investigations with Hydroides elegans larvae have shown that the settlement-inducing activity of a $3 \mathrm{~d}$ old natural biofilm was not affected by streptomycin, indicating that the bacterial surface consisted of viable, streptomycin-resistant strains causing larval settlement (S. C. K. Lau pers. comm.). Among the 46 bacterial strains isolated from marine natural biofilms so far, 19 strains have been shown to have a strong inductive effect and, therefore, to be responsible for the overall settlement activity of natural bio-organic films (Lau \& Qian 1997. Unabia \& Hadfield 1999). These reports suggest that the metamorphic response in bioassays performed in the presence of antibiotics was likely elicited by specific bacterial strains, which are resistant to a combination of penicillin and streptomycin. However, the exact nature of the larval metamorphic response to these inductive bacterial strains and the processes underlying the variant sensitivity of these particular strains to antibiotics still need to be further characterized before a final conclusion can be reached.

Our results indicate that the impact of inadvertently inoculated bacteria has been underestimated in our preceding studies on larval metamorphic induction by chemical cues in laboratory bioassays (Bryan et al. 1997. Harder \& Qian 1999). Bacteria were inoculated into test dishes despite aseptic techniques as they were found to be associated with larvae and suspended in the larval batch water. Therefore, we conclude that still-water laboratory bioassays with putative signaling compounds are generally inappropriate as long as these substances may serve as a nutrition source for film-forming marine bacteria. If larvae are highly responsive to natural marine biofilms, such as in the case of Hydroides elegans (Lau \& Qian 1997) and Pomatoceros lamarckii (Chan \& Walker 1998), then this kind of bioassay cannot be evaluated with regard to an explicit investigation of a putative chemical metamorphic cue's efficacy. The same conclusion applies in a case where a biofilm is a prerequisite for larval settlement, such as in $H$. dianthus (Toonen \& Pawlik 1996).

For a number of marine invertebrates, artificial inducers have been investigated with regard to their potential for influencing larval metamorphosis. The neurotransmitters GABA, in the case of the red abalone Haliotis rufenses (Slattery 1992, Bryan \& Qian 1998, Searcy \& Anguiano 1998), and DOPA, in the case of a variety of other marine invertebrates (Waite 1992, Rodriguez et al. 1993), are known to be involved in transduction of signals triggering metamorphosis. However, GABA (Kaspar et al. 1991), catecholamines (Kinney et al. 1999) or other nutritional compounds such as DFAA, DNA or ammonia (Amano et al. 1982, Jørgensen et al. 1993, Bhosle \& Wagh 1997) display valuable carbon, nitrogen and energy sources which have been shown to be readily metabolized by marine bacteria. In this regard, the results of our present study coincide with the outcome of previous investigations by others in the sense that marine bacteria have the potential to affect invertebrate larval settlement by removing organic substances from the settlement habitat (Johnson at al. 1991, Johnson \& Sutton 1994, Kaspar \& Mountfort 1995, Anderson 1996, Fleck \& Fitt 1999). In light of these findings, an overhaul of previous studies on larval metamorphosis may be required.

Considering the transformation of the composite amino acid cue into a bioactive bacterial film under the conditions of the laboratory bioassay, it seems questionable whether similar determinants will trigger attachment and metamorphosis of competent larvae of Hydroides elegans under natural conditions. Firstly, in the laboratory bioassay larvae were kept in a confined volume of $4.5 \mathrm{ml}$ seawater for at least $24 \mathrm{~h}$. The close proximity of larvae to a settlement cue and/or substratum for more than $12 \mathrm{~h}$ may not occur in field conditions unless larvae are trapped in currents caused by surface topography and hydrodynamics (Walters et al. 
1997). Secondly, the metamorphic response to a bacterial film is much faster (Carpizo-Ituarte \& Hadfield 1998, this study) than actually observed in our laboratory bioassays with natural isolates (Harder \& Qian 1999). We demonstrated that the metamorphic response to amino acids was delayed for at least $12 \mathrm{~h}$ in contrast to the rapid response to pre-filmed surfaces. The probability of larvae encountering and responding to attractive biofilmed surfaces may be much higher than a hypothetical retention in close proximity to biotic amino acid sources in the field for at least $12 \mathrm{~h}$. Thirdly, with bacterial uptake rates as high as reported in this study, it seems unlikely that DFAA would have ever evolved as a natural settlement cue which is perceived by competent larvae directly.

Since we found no evidence for waterborne metamorphic inducers, we assume that rapid and active substratum selection by Hydroides elegans larvae is caused by few inductive bacterial strains in the complex biofilm matrix. Larval settlement may be enhanced in a region with a favorable bacterial film matrix as a consequence of high nutrient efflux (e.g. sewage) into a shallow marine environment (e.g. harbor areas, secluded bays, fish-farming grounds). Hence, a change in the nutritional composition should affect both the quantity and quality of the bacterial film composition and consequently the larval settlement response. On a smaller scale, this effect was observed in Expt 3. Evidently, the 0.5kDF was comprised of a larger amount of dissolved organic matter than the AAS, which consisted of 10 polar amino acids only (Table 1, Harder \& Qian 1999). The DFAA analysis in the presence of antibiotics revealed that non-polar amino acids in the $0.5 \mathrm{kDF}$ were generally utilized first (Figs. $7 \& 8$ ). Consequently, the $0.5 \mathrm{kDF}$ led to higher densities of resistant bacteria and, therefore, caused a significantly higher metamorphic response compared to the AAS after $24 \mathrm{~h}$ (Fig. 4).

In light of our study and the results of preceding investigations, we conclude that specific bacterial strains in the complex biofilm matrix account for the induction of larval settlement and metamorphosis in Hydroides elegans. Nonetheless, further analysis has to be performed in a concerted effort to elucidate the still unknown metamorphic properties of inductive bacteria.

Acknowledgements. The authors thank S. C. K. Lau for his valuable comments on the manuscript, $L$. Soo for technical support, A. Poon and T Wong for assistance in algal culture, and S. C. K. Lau and J. W. Qiu for statistical consultation. This study was supported by a RGC grant (HKUST 651/96M) to P.-Y.Q.

\section{LITERATURE CITED}

Amano M. Hara S, Taga N (1982) Utilization of dissolved amino acids in seawater by marine bacteria. Mar Biol 68:31-36

Anderson MJ (1996) A chemical cue induces settlement of Sydney rock oysters, Saccostrea commercialis, in the laboratory and in the field. Biol Bull 190:350-358

Attrassi B, Saghi M, Flatau G (1993) Multiple antibiotic-resistance of bacteria in Atlantic coast (Marocco). Environ Technol 14:1179-1186

Azam E, Cho BC (1987) Bacterial utilization of organic matter in the sea. In: Fletscher M, Gray TRG, Jones JG (eds) Ecology of microbial communities. Cambridge University Press, Cambridge, p 261-281

Baloun AJ, Morse DE (1984) Ionic control of settlement and metamorphosis in larval Haliotis rufescens (Gastropoda). Biol Bull 167:124-138

Bhosle NB, Wagh AB (1997) Amino acids in biofilm material on aluminium panels immersed in marine waters. Biofouling 11:149-166

Browne KA, Tamburri MN, Zimmer-Faust RK (1998) Modeling quantitative structure-activity relationships between animal behaviour and environmental signal molecules. J Exp Biol 201:245-258

Bryan PJ, Qian PY, Kreider JL, Chia FS (1997) Induction of larval settlement by pharmacological and conspecific associated compounds in the serpulid polychaete Hydroides elegans. Mar Ecol Prog Ser 146:81-90

Bryan PJ, Kreider JL, Qian PY (1998) Settlement of the serpulid polychaete Hydroides elegans (Haswell) on the arborescent bryozoan Bugula neritina (L.): evidence of a chemically mediated relationship. J Exp Mar Biol Ecol 220:171-190

Butman CA (1987) Larval settlement of soft-sediment invertebrates: the spatial scales of pattern explained by active habitat selection and the emerging role of hydrodynamical processes. Oceanogr Mar Biol Annu Rev 25:113-165

Carpizo-Ituarte E. Hadfield MG (1998) Stimulation of metamorphosis in the polychaete Hydroides elegans Haswell (Serpulidae). Biol Bull 194:14-24

Chan ALC, Walker G (1998) The settlement of Pomatoceros lamarckii larvae (Polychaeta: Sabellida: Serpulidae): a laboratory study. Biofouling 12:71-80

Coffin RB (1989) Bacterial uptake of dissolved free and combined amino acids in estuarine waters. Limnol Oceanogr 34:531-542

Conover WJ, Iman L (1981) Rank transformations as a bridge between parametric and nonparametric statistics. Am Stat 35: $124-129$

Crawford CC, Hobbie JE, Webb KL (1974) The utilization of dissolved free amino acids by estuarine microorganisms. Ecology 55:551-563

Crisp DJ (1974) Factors influencing the settlement of marine invertebrate larvae. In: Grant PT, Mackie AM (eds) Chemoreception in marine organisms. Academic Press, London, p 177-265

Crisp DJ (1984) Overview of research on marine invertebrate larvae, 1940-1980. In: Costlow JD, Tipper RC (eds) Marine biodeterioration: an interdisciplinary study. Naval Institute Press, Annapolis, MD, p 103-126

Dias JCDR, Ernandez D, Hofer E (1991) Antibiotic-resistance in NON-01 Vibrio-cholera and Y-Parahaemolyticus. Rev Microbiol 22:28-33

Ferguson RL, Sunda WG (1984) Utilization of amino acids by planktonic marine bacteria: importance of clean technique and low substrate additions. Limnol Oceanogr 29(2): $258-274$ 
Fleck J, Fitt WK (1999) Degrading mangrove leaves of Rhizophora mangle Linne provide a natural cue for settlement and metamorphosis of the upside down jellyfish Cassiopea xamachana Bigelow. J Exp Mar Biol Ecol 234: 83-94

Gerhardt P, Murray RGE, Willis A, Noel R (1994) Methods for general molecular bacteriology. American Society for Microbiology, Washington, DC

Hadfield MG (1986) Settlement and recruitment of marine invertebrates: a perspective and some proposals. Bull Mar Sci 39:418-425

Hadfield MG, Unabia CC, Smith CM, Michael TM (1994) Settlement preferences of the ubiquitous fouler Hydroides elegans. In: Thompson MF, Nagabhushanam R, Sarojni R, Fingerman $M$ (eds) Recent developments in biofouling control. AA Balkema, Rotterdam, p 65-74

Harder T, Qian PY (1999) Induction of larval attachment and metamorphosis in the serpulid polychaete Hydroides elegans by dissolved free amino acids: isolation and identification. Mar Ecol Prog Ser 179:259-271

Hoppe HG (1991) Microbial extracellular enzyme activity: a new key parameter in aquatic ecology. In: Chrost RJ (ed) Microbial enzymes in aquatic environments. SpringerVerlag, New York, p 60-95

Jensen RA, Morse DE (1990) Chemically induced metamorphosis of polychaete larvae in both the laboratory and the ocean environment. J Chem Ecol 16:911-930

Johnson CR, Sutton DC (1994) Bacteria on the surface of crustose coralline algae induce metamorphosis of the crown-of-thorns starfish Acanthaster planci. Mar Biol 120: 305-310

Johnson CR, Muir DG, Reysenbach AL (1991) Characteristic bacteria associated with surface of coralline algae-a hypothesis for bacterial induction of marine invertebrate larvae. Mar Ecol Prog Ser 74:281-294

Jørgensen NOG, Kroer N, Coffin RB, Yang XH, Lee C (1993) Dissolved free amino acids, combined amino acids, and DNA as sources of carbon and nitrogen to marine bacteria. Mar Ecol Prog Ser 98:135-148

Kaspar FK, Mountdort DO (1995) Microbial-production and degradation of gamma-aminobutyric acid (GABA) in the abalone larval settlement habitat. FEMS Microbiol Ecol $17: 205-211$

Kaspar FK, Mountfort DO, Pybus V (1991) Degradation of gamma-aminobutyric acid (GABA) by marine microorganisms. FEMS Microbiol Ecol 85:313-318

Kinney KS, Austin CE, Morton DS, Sonnenfeld G (1999) Catecholamine enhancement of Aeromonas hydrophila growth. Microb Pathog 26: 85-91

Lau SCK, Qian PY (1997) Phlorotannins and related compounds as larval settlement inhibitors of the tube-building polychaete Hydroides elegans. Mar Ecol Prog Ser 159: 219-227

Lindroth P, Mopper K (1979) High-performance liquid chro-

Editorial responsibility: Otto Kinne (Editor),

Oldendorf/Luhe, Germany matographic determination of subpicomole amounts of amino acids by precolumn fluorescence derivatization with o-phthaldialdehyde. Anal Chem 51:1667-1674

Morse DE (1990) Recent progress in larval settlement and metamorphosis: closing the gaps between molecular biology and ecology. Bull Mar Sci 46:465-483

Pawlik JR (1992) Chemical ecology of the settlement of benthic marine invertebrates. Oceanogr Mar Biol Annu Rev 30:273-335

Rodriguez SR, Ojeda FP, Inestrosa NC (1993) Settlement of benthic marine invertebrates. Mar Ecol Prog Ser 97 : $193-207$

Ryland JS (1974) Behavior, settlement and metamorphosis of bryozoan larvae: a review. Thallassia Jugosl 10:239-262

Ryland JS (1977) Taxes and tropisms of bryozoans. In: Woollacott RM, Zimmer RL (eds) Biology of bryozoans. Academic Press, New York, p 411-436

Scheltema RS (1974) Biological interactions determining larval settlement of marine invertebrates. Thalassia Jugosl $10: 263-269$

Searcy BR, Anguiano BC (1998) Optimizing the concentration of gamma-aminobutyric acid (GABA) for inducing larval metamorphosis in the red abalone Haliotis rufescens (Mollusca: Gastropoda). J World Aquacult Soc 29:463-470

Shapiro SS, Wilk MB (1965) An analysis of variance test for normality (complete samples). Biometrika 52:591-611

Simon M (1991) Isotope dilution of intracellular amino acids as tracer of carbon and nitrogen sources of marine planktonic bacteria. Mar Ecol Progr Ser 74:295-301

Slattery M (1992) Larval settlement and juvenile survival in the red abalone (Haliotis rufescens) - an examination of inductive cues and substrate selection. Aquaculture 102: $143-153$

Toonen JP, Pawlik JR (1996) Settlement of the tube worm Hydroides dianthus (Polychaeta: Serpulidae): cues for gregarious settlement. Mar Biol 126:725-733

Unabia CRC, Hadfield MG (1999) Role of bacteria in larval settlement and metamorphosis of the polychaete $\mathrm{Hy}$ droides elegans. Mar Biol 133:55-64

Waite JH (1992) The DOPA ephemera: a recurrent motif in invertebrates. Biol Bull 183:178-184

Walters LJ, Hadfield MG, del Carmen KA (1997) The importance of larval choice and hydrodynamics in creating aggregations of Hydroides elegans (Polychaeta: Serpulidae). Invertebr Biol 116:102-114

Yool AJ, Grau SM, Hadfield MG, Jenssen RA, Markell DA, Morse DE (1986) Excess potassium induces larval metamorphosis of four marine invertebrate species. Biol Bull (Woods Hole) 170:255-266

Zar JH (1996) Biostatistical analysis. 3rd edn. Prentice Hall International, Inc, Upper Saddle River, NJ

Zobell CE, Allen EC (1935) The significance of marine bacteria in the fouling of submerged surfaces. J Bacteriol 29(3):239-251

Submitted: December 28, 1998; Accepted: July 5, 1999

Proofs received from author(s): November 22, 1999 